\title{
Tworzenie okupacyjnego wymiaru sprawiedliwości w Generalnym Gubernatorstwie w latach 1939-1940
}

\section{Schaffung des Besatzungsgerichtswesens im Generalgouvernement in den Jahren 1939-1940}

1. Wprowadzenie. 2. Administracja wymiaru sprawiedliwości. 3. Pierwszy etap tworzenia sądownictwa okupacyjnego (IX 1939 - 19 II 1940): 3.1. Niemieckie sądy wojskowe; 3.2. Wojskowe sądy doraźne; 3.3. Sądy doraźne tworzone przez policję niemiecką lub przez ,podgrupy operacyjne" SS; 3.4. Jednolite policyjne sądy doraźne w Generalnym Gubernatorstwie; 3.5. Niemieckie sądy specjalne; 3.6. Sądy specjalne w Generalnym Gubernatorstwie. 4. Drugi etap tworzenia sądownictwa okupacyjnego (po 19 II 1940 r.): 4.1. Sądownictwo niemieckie; 4.2. Sądownictwo polskie.

1. Einführung. 2.Verwaltung des Rechtswesens. 3. Die erste Etappe der Schaffung des Okupationsgerichtswesens (IX 1939-19 II 1940): 3.1. Deutsche Militärgerichte; 3.2. Militärische Standgerichte; 3.3. Durch die deutsche Polizei und "Einsatzgruppen der Sicherheitspolizei" gebildete Standgerichte; 3.4. Einheitliche polizeiliche Standgerichte im Generalgouvernement; 3.5. Sondergerichte; 3.6. Sondergerichte im Generalgouvernement. 4. Die zweite Etappe der Bildung der Okupationsgerichtsbarkeit (nach dem 19 II 1940): 4.1. Deutsche Gerichtsbarkeit; 4.2. Polnische Gerichtsbarkeit.

1. Kształtowanie okupacyjnego wymiaru sprawiedliwości w Generalnym Gubernatorstwie było $w$ dużej mierze uwarunkowane ogólnymi założeniami polityki III Rzeszy w stosunku do ziem polskich zdobytych w 1939 r. Wśród gremiów kierowniczych agresora nie budziła wątpliwości decyzja o wcieleniu części terytorium Polski do Rzeszy Niemieckiej. Došć długo natomiast ważył się zasięg tej aneksji. Ostatecznie do Rzeszy zostaly wlączone: województwo pomorskie, poznańskie, górnośląskie, część województwa łódzkiego z Lodzią, zachodnia część województwa krakowskiego, północna część województwa warszawskiego, powiat suwalski i zachodnia część województwa kieleckiego; poza tym do Niemiec wcielono Wolne Miasto Gdańsk. Obszar anektowany do Rzeszy w 1939 r. obejmowal blisko 92 tys. $\mathrm{km}^{21}$.

1 Cz. Madajczyk, Polityka III Rzeszy w okupowanej Polsce, t. I, Warszawa 1968, s. 66; J. Bardach, B. Leśnodorski, M. Pietrzak, Historia ustroju i prawa polskiego, Warszawa 1998, s. 584. 
$\mathrm{Na}$ terenach wcielonych do III Rzeszy wprowadzono niemiecką strukturę wymiaru sprawiedliwości przez włączenie terenów polskich do dotychczasowych okregów wyższych sądów krajowych (Oberlandgerichte) lub tworząc w $1940 \mathrm{r}$. nowe okręgi: dla wyższych sądów krajowych w Poznaniu i Gdańsku, a w 1941 r. - w Katowicach. Zostały one oczywiście podporządkowane ministerstwu sprawiedliwości Rzeszy. W ramach niemieckich struktur wymiaru sprawiedliwości na ziemiach polskich wcielonych do Rzeszy mialy swoje siedziby: sądy lokalne (Amtsgerichte) - w literaturze używane jest też określenie sądy powiatowe lub sądy obwodowe; sądy krajowe (Landgerichte) i wspomniane już wyższe sądy krajowe, które stanowily system sądownictwa powszechnego. Obok nich istniały sądy specjalne (Sondergerichte); na terenach anektowanych $\mathrm{w}$ różnym czasie funkcjonowały one w: Poznaniu, Bydgoszczy, Łodzi, Katowicach, Gdańsku, Kaliszu, Ciechanowie, Grudziądzu, Toruniu, Chojnicach, Przasnyszu i Płocku. Na ziemie wcielone do Rzeszy rozciągnęly też swoje kompetencje: Trybunał Rzeszy w Lipsku (Reichsgericht) i Trybunał Narodowy (Volksgerichtshof) ${ }^{2}$.

Dłużej ważyły się losy centralnych terenów Polski. Hitler rozważał koncepcję utworzenia polskiego państwa buforowego. Wydaje się, że plany te nie zostały zrealizowane głównie ze względu na postawę Anglii i Francji, które nie zgodziły się na zawarcie separatystycznego pokoju ${ }^{3}$. W rezultacie, 12 października 1939 r. powstało Generalne Gubernatorstwo dla okupowanych polskich obszarów ze stolicą w Krakowie - twór o niejasno określonym statusie państwowym, który został faktycznie podporządkowany suwerenności Rzeszy Niemieckiej. Celem nadrzędnym realizowanej na tym terenie władzy prawodawczej okupanta był interes Rzeszy ${ }^{4}$. Przedstawiciel władz centralnych GG koordynujący ustawodawstwo okupacyjne - dr Albert Weh argumentowal,

${ }^{2}$ Dziennik Ustaw Rzeszy Niemieckiej - Reichsgesetzblatt [dalej: RGBI] 1940, cz. I, s. 1538-1539; A. K on i ec z y , Pod rzqdami wojennego prawa karnego III Rzeszy. Górny Ślask 1939-1945, Warszawa-Wroclaw 1972, s. 166; t e nże, Organizacja wymiaru sprawiedliwości na Ślasku w latach II wojny światowej, „Acta Universitatis Wratislaviensis” 1966, Prawo CCXLIX: Studia Historyczno-Prawne, red. A. Konieczny, Wrockaw, s. 177, 184-194; E. Zarzycki. Eksterminacyjna $i$ dysḱryminacyjna dzialalność hitlerowskich sq̨dów okręgu Gdańsk - Prusy Zachodnie w latach 1939-1945, Bydgoszcz 1981, s. 13-23; S. Godlewsk i, Sqdownictwo III Rzeszy na okupowanych terenach Polski wlaczonych do Rzeszy, [w:] Zbrodnie i sprawcy, red. Cz. Pilichowski, Warszawa 1980, s. 526-543 i in.

${ }^{3}$ Cz. Madajczyk, Polityka..., t. I, s. $90-99$.

${ }^{4}$ A. K la fk owski, Okupacja niemiecka w Polsce w świetle prawa narodów, Poznań 1946, s. 58-60; Prawo Generalnego Gubernatorstwa w ukladzie rzeczowym z objaśnieniami i szczególowym skorowidzem, wyd. A. Weh, Kraków 1941 [dalej: Prawo GG], A 100: Dekret führera i kanclerza Rzeszy Niemieckiej o administracji okupowanych polskich obszarów z 12 X 1939 r. Faktyczne przeniesienie siedziby generalnego gubernatora do Krakowa nastąpiło dopiero 8 XI $1939 \mathrm{r}$. Do tego momentu urzędował on w Lodzi (al. Kościuszki 15). Archiwum Federalne w Berlinie - Bundesarchiv Berlin [dalej: BB], R 3001, Ministerstwo Sprawiedliwości Rzeszy - Reichsjustizministerium, sygn. 9803/9, k. 7 . 
że suwerenność Państwa Polskiego została zlikwidowana (debelliert ist) ${ }^{5}$. Zwierzchnik administracji okupacyjnej - generalny gubernator Hans Frank podkreślał nadrzędność interesów Rzeszy Niemieckiej i z dumą interpretował zmiany statusu podległego mu terytorium. W okresie od października 1939 r. do lipca 1940 r. obowiązywała oficjalna nazwa: „Generalne Gubernatorstwo dla okupowanych polskich obszarów". W dniu 31 lipca $1940 \mathrm{r}$. Frank wydal dekret o zmianie nazwy na "Generalne Gubernatorstwo", powolując się na udzielone mu przez Hitlera upoważnienie. Miało to świadczyć o bliższym związku z Rzeszą ${ }^{6}$.

$\mathrm{Z}$ dniem 26 października $1939 \mathrm{r}$. ustanowione zostało rozporządzenie o odbudowie wymiaru sprawiedliwości w GG, w którym zapowiedziano powołanie do życia dualistycznego systemu sądownictwa: sądów niemieckich i sądów polskich, przy czym sądownictwo niemieckie uzyskało kontrolę nad polskim ${ }^{7}$. Ten dualistyczny model był rozwiązaniem dotychczas nie stosowanym przez hitlerowców. Warto podkreślić, że władze III Rzeszy rozważały także koncepcje utrzymywania porządku na terenie GG za pomocą policyjnych środków przymusu, z pozbawieniem miejscowej ludności ochrony przez jakikolwiek system prawny. Koncepcja ta zostala jednak odrzucona glównie ze względów gospodarczych: ponieważ GG miało się stać obiektem wyzysku ze strony Rzeszy, to za niedopuszczalne uznano stosowanie wyłącznie środków policyjnych, gdyż uniemożliwiałyby one normalne funkcjonowanie życia gospodarczego. U źródel dualizmu wymiaru sprawiedliwości legła idea segregacji narodowej i izolacji Niemców od miejscowej ludności (cienka niemiecka warstwa panów na kolonialnym obszarze Wschodu) ${ }^{8}$. Dzięki zastosowaniu tego modelu Niemcy zamieszkujący GG podlegali wyłącznie jurysdykcji niemieckiego wymiaru sprawiedliwości - „,0trzymywali prawo od niemieckiego sędziego". Podkreślano także prymat niemieckiego prawa nad polskim ustawodawstwem, gdyż w GG miały obowiązywać te $z$ przepisów polskiego prawa, które nie pozostawały w sprzeczności z przejęciem władzy przez Rzeszę Niemiecką i wykonywaniem wojskowych praw zwierzchnich?.

${ }^{5} \mathrm{~J}$. B ü hler (herausgegeben von), Das Generalgouvernement. Seine Verwaltung und seine Wirtschaft, Kraków 1943, s. 61 - w ramach rozdz. III oprac. przez A. Weha: Die Rechtlichen Grundlagen des Generalgouvernements.

${ }^{6}$ Prawo GG, A 102: Dekret w sprawie nowych uregulowan organizacyjnych w GG z 31 VII $1940 \mathrm{r}$.

${ }^{7}$ Prawo GG, C 100: Rozporządzenie o odbudowie wymiaru sprawiedliwości w GG z $26 \mathrm{X}$ 1939 r., $\& 1-4$.

${ }^{8}$ D. M a jer, "Narodowo obcy w III Rzeszy". Przyczynek do narodowo-socjalistycznego ustawodawstwa $i$ praktyki prawniczej $w$ administracji $i$ wymiarze sprawiedliwości ze szczególnym uwzględnieniem ziem wcielonych do Rzeszy $i$ Generalnego Gubernatorstwa, Warszawa 1989, s. 319.

${ }^{9}$ Ibidem, s. 318; Prawo GG, A 100, § 4. 
2. $\mathrm{Na}$ początku wojny na terenach zajętych przez wojska niemieckie najwyższą władzę sprawował naczelny dowódca wojsk lądowych gen. von Brauchitsch. Przekazal on swoje uprawnienia dowódcom poszczególnych armii. U ich boku działali szefowie zarządów cywilnych, którzy tworzyli administrację $\mathrm{i}$ policje na obszarach zajętych przez poszczególne armie ${ }^{10}$. System ten uległ zmianie, gdy wojska niemieckie znalazly się w głębi Polski. 25 września 1939 r. ukazal się dekret Hitlera, na podstawie którego utworzono cztery okupacyjne okręgi wojskowe (Militärbezirke): Gdańsk-Prusy Zachodnie, Poznań, Kraków i Łódź. Dowódcom wojskowym tych okręgów przydzielono szefów zarządu cywilnego. Minister Rzeszy Hans Frank otrzymal wówczas nominacje na naczelnego szefa administracji (Oberster Verwaltungschef) okupowanych ziem Polski ${ }^{11}$.

W ramach tego systemu administracją wymiaru sprawiedliwości zajmowali się szefowie zarządów cywilnych i podlegli im pełnomocnicy ministerstwa sprawiedliwości do spraw sądownictwa (Beauftragte des Reichsjustizministeriums für die Justizangelegenheiten ${ }^{12}$. Nadzorowali oni tworzone $w$ trakcie działan wojennych sądy specjalne i składali wnioski do ministerstwa sprawiedliwości o uruchomienie nowych. Otrzymywali kopie zapadłych w tych sądach wyroków. Ustanawiali reguły i porządek zastępstwa sędziów i prokuratorów pomiędzy dwoma sąsiadującymi ze sobą ośrođkami okupacyjnego wymiaru sprawiedliwości ${ }^{13}$. We wrześniu $1939 \mathrm{r}$. podjęte zostały także działania zmierzające do uruchomienia sądownictwa cywilnego. Na konferencji w dniu 19 września w Częstochowie skierowano do zwierzchników powiatowej administracji okupacyjnej - landratów apel o nadzór, a także o współdziałanie w tej kwestii z sądami specjalnymi. Organizowanie cywilnego wymiaru

${ }^{10} \mathrm{Cz} . \mathrm{M}$ ad a jczyk, Polityka..., t. I, s. 50-51.

"Struktura i funkcjonowanie niemieckiego zarządu wojskowego w Polsce zostały omówione w: L. He rzog, Niemieckie sily zbrojne $w$ okupowanej Polsce $w$ latach 1939-1941, cz. I, „Wojskowy Przegląd Historyczny” [dalej: WPH] 1961, R. VI, z. 4, s. 88-133; cz. II, WPH 1962, R. VII, z. 1, s. 45-71; K. R adziwończyk, Okupacyjny zarzqd $i$ zbrodnie wojenne Wehrmachtu podczas agresji na Polske, WPH 1973, R. XVIII, z. 2, s. 101-102; R. H erzog, Grundzüge der deutschen Besatzungsverwaltung in den ost- und südosteuropäischen Ländern während des zweiten Weltkrieges, Tübingen 1955, s. 84.

${ }^{12} \mathrm{~Np}$. na obszarze tyłowym 8. armii pełnomocnikiem był baron von Thiesenhausen, na obszarze 10. armii - prezes sądu krajowego Nebesky, a w sztabie szefa zarządu cywilnego przy dowódcy 3. Odcinka Ochrony Pogranicza - radca sądu krajowego Schmidt (A. K o n i e cz ny, Organizacja..., s. 186-187). Zastępcą Nebesky'ego ustanowiony został 1 X 1939 r. przewodniczący Sądu Specjalnego w Radomiu von Wojkowsky-Biedau. Archiwum Państwowe w Lodzi [dalej: APL], Sąd Specjalny w Piotrkowie [dalej: SSpP], sygn. 1, k. 3, 9, 24.

13 Np. zastępstwo prokuratorów i sędziów Sądu Specjalnego $\mathrm{nr}$ I w Częstochowie i nr II w Piotrkowie oraz zastępstwo prokuratorów i sędziów Sądu Specjalnego nr III w Kielcach i nr IV w Radomiu. Pełnomocnik do spraw sądownictwa Nebesky zajmowal się nawet zmianą pieczęci w przypadku zmiany siedziby sądu specjalnego (przeniesienie z Wielunia do Piotrkowa Trybunalskiego). APL, SSpP, sygn. 1, k. 3, 8, 24. 
sprawiedliwości, a w szczególności sądownictwa niespornego powierzono sędziom sądów specjalnych, którzy mieli to czynić obok swych podstawowych obowiązków. To jednak wywolało komplikacje, gdyż kłóciło się z zasadą stałej gotowości sędziów sądów specjalnych. W związku z tym rozważano możliwość zwiększenia obsady kadrowej sądów. Bezpośredni nadzór nad sądownictwem okupowanych polskich terenów sprawowało też ministerstwo sprawiedliwości Rzeszy. 24 października 1939 r. odbyla się w Berlinie konferencja przewodniczących sądów specjalnych funkcjonujących na zajętych terytoriach państwa polskiego, pod przewodnictwem sekretarza stanu Freislera, na której dokonano podsumowania dotychczasowej działalności i sformułowano zalecenia na przyszłośćc ${ }^{14}$.

Po utworzeniu Generalnego Gubernatorstwa nadzór administracyjny nad sądownictwem powierzono głównemu wydziałowi sprawiedliwości (Hauptabteilung Justiz) przy Urzędzie Generalnego Gubernatora. Od 9 grudnia 1940 r. Urząd Generalnego Gubernatora przekształcony został w Rząd Generalnego Gubernatorstwa. Na czele glównego wydziału sprawiedliwości stał Kurt Wille, który został oddelegowany do dyspozycji Franka przez ministra sprawiedliwości Rzeszy w dniu 11 października 1939 r. Na szczeblu dystryktu nadzór administracyjny nad sądownictwem wykonywał wydział sprawiedliwości (Abteilung Justiz) w urzędzie szefa dystryktu ${ }^{15}$. Wydziały sprawiedliwości $w$ poszczególnych dystryktach dzielily się na referaty ${ }^{16}$. Diemut Majer pisze, że administracja wymiaru sprawiedliwości w GG była odizolowana od struktury aparatu wymiaru sprawiedliwości w Rzeszy. Ani kierownik głównego wydziału sprawiedliwości w rządzie GG, ani kierownicy wyższych sądów niemieckich nie brali udziału $w$ regularnych naradach najwyższych urzędników wymiaru sprawiedliwości w Rzeszy. Nie musieli oni składać żadnych raportów lub sprawozdań Ministerstwu Sprawiedliwości Rzeszy, ani też nie otrzymywali wytycznych i zaleceń wydawanych przez to ministerstwo ${ }^{17}$. Nie była to jednak z pewnością izolacja całkowita. Urzędnicy organizujący aparat wymiaru sprawiedliwości w GG w 1939 r. rekrutowali się z ministerstwa i byli opłacani z Kasy Głównej Rzeszy (Reichshauptkasse).

${ }^{14}$ APL, SSpP, k. 2, 3, 14, 15, 22, 23; BB, R 3001, sygn. 9803/7/1, k. 23-25, 56-58.

is $\mathrm{Cz}$. M adajczyk, Polityka.., t. I, s. 107-120; R. Herzog, Grundzüge..., s. 96-98. Charakterystyczny był fakt, że mimo oddelegowania do dyspozycji Franka, zarówno pensja, jak i dodatek ministerialny Willego nadal byly wypłacane z glównej kasy Rzeszy; BB, R 3001, sygn. 2959 , k. 25.

${ }^{16} \mathrm{Na}$ przyklad w dystrykcie radomskim na początku 1940 r. wydział sprawiedliwości dzielił się na 5 referatów. Referat I zajmował się tworzeniem sądownictwa niemieckiego, referat II nadzorował reaktywowane sądownictwo polskie, referaty III i IV przygotowywały zarządzenia i obwieszczenia do publikacji w dzienniku urzędowym (Amtsblatt), referat V sprawował nadzór nad sądownictwem. Archiwum Państwowe w Radomiu [dalej: APR], Gubernator Dystryktu Radom [dalej: GDR], sygn. 37, k. 7, 38; sygn. 206, k. 11.

${ }^{17}$ D. M a jer, Fremdvölkische im Dritten Reich, Boppard am Rhein 1993, 2, s. 851. 
Kasa ta domagała się od Wydziału Finansów w rządzie GG kwoty 40.275,47 marek - jako zwrotu za pobory wypłacone oddelegowanym do GG dwunastu pracownikom Ministerstwa Sprawiedliwości Rzeszy z Kurtem Wille na czele (za okres 1 kwietnia - 30 września 1940 r.) W marcu 1940 r. minister sprawiedliwości Rzeszy oddelegował specjalnych urzędników ze swego resortu, aby objęli nadzór nad sprawami finansowymi wymiaru sprawiedliwości w GG. Kurt Wille skierowal ich wówczas do czterech dystryktów. Poza tym należy pamiętać, że we wszystkich organach niemieckiego okupacyjnego wymiaru sprawiedliwości (sądach, prokuraturach) wprowadzono obowiązek prenumeraty najbardziej reprezentatywnych czasopism prawniczych Rzeszy: „Deutsche Justiz” i „Deutsches Recht”18.

Proces formowania okupacyjnego wymiaru sprawiedliwości w latach 1939-1940 można podzielić na dwa etapy. Pierwszy z nich obejmuje okres zarządu wojskowego oraz tworzenie organów jurysdykcyjnych i administracji sprawiedliwości Generalnego Gubernatorstwa pod koniec 1939 r. i na początku $1940 \mathrm{r}$. Drugi etap rozpoczyna się 19 lutego 1940 r., wraz $\mathrm{z}$ ogłoszeniem $\mathrm{i}$ wejściem $\mathrm{w}$ życie dwóch rozporządzeń generalnego gubernatora: o sądownictwie niemieckim w GG i o sądownictwie polskim w GG, co można uznać za kontynuacje postanowień wspomnianego wyżej rozporządzenia z 26 października 1939 r. i realizacje dualistycznego modelu wymiaru sprawiedliwości ${ }^{19}$.

3. W pierwszym $\mathrm{z}$ wyróżnionych to okresów (wrzesień 1939 r. - 19 luty 1940 r.) funkcjonowały na ziemiach polskich sądy utworzone w czasie zarządu wojskowego i sądy ustanowione przez władze Generalnego Gubernatorstwa. Były to:

1. sądy wojskowe (Militärgerichte) - działały od chwili wybuchu wojny do końca okupacji;

2. wojskowe sądy doraźne (militärische Standgerichte) tworzone przez jednostki Wehrmachtu; działały one od 12 września 1939 r. do 26 stycznia 1940 r.;

3. sądy doraźne (Standgerichte) tworzone przez policję niemiecką lub przez „,podgrupy operacyjne" SS; funkcjonowały one od 21 września $1939 \mathrm{r}$. do 31 października 1939 r.;

4. jednolite policyjne sądy doraźne (Standgerichte) w GG; funkcjonowały one od 31 października 1939 r. do końca okupacji;

5. sądy specjalne (Sondergerichte) - utworzone w okresie zarządu wojskowego, funkcjonowały od 5 września 1939 r. do 15 listopada 1939 r.;

${ }^{18}$ APR, GDR, sygn. 200, k. 1-28; sygn. 259, k. 6; sygn. 264, k. 1-3: BB, R 3001, sygn. 2959, k. 25, 34, 60 .

19 Prawo GG, C 120; Rozporządzenie z 19 II 1940 r. o sądownictwie niemieckim w GG;

C 150: Rozporządzenie z 19 II 1940 r. o sądownictwie polskim w GG. 
6. sądy specjalne w GG (Sondergerichte im Generalgouvernement); działaly one od 15 listopada 1939 r. do końca okupacji, z tym że 5 lipca 1943 r. połączono je $z$ powstałymi $w$ drugim etapie sądami niemieckimi i odtąd nosily nazwę: Sąd Specjalny przy Sądzie Niemieckim w... (Sondergericht bei dem Deutschen Gericht in...). Przy sądach specjalnych usytuowana była też niemiecka prokuratura ${ }^{20}$.

3.1. Już $w$ chwili wybuchu wojny na stopniowo zdobywanych ziemiach zaczęły sprawować władzę niemieckie sądy wojskowe (Militärgerichte). Podstawą prawną ich funkcjonowania podczas wojny stały się dwa rozporządzenia (opracowane jeszcze w 1938 r., a wprowadzone przez naczelnego dowódcę sił zbrojnych 26 sierpnia 1939 r.) (1) rozporządzenie o niemieckim prawie karnym w czasie wojny i w czasie akcji specjalnych oraz (2) rozporządzenie $o$ wojskowym postępowaniu karnym $w$ czasie wojny i w czasie akcji specjalnych. Ich efektem było bardzo uproszczone postępowanie wobec oskarżonego, którego należało przesłuchać co do okoliczności objętych aktem oskarżenia i udzielić ostatniego słowa. W przypadku braku szczegółowych przepisów sąd kierowal się własnym uznaniem. Przewidziano udział obrońcy, którym mógł być każdy, ale tylko wtedy, gdy przestępstwo popełnione przez oskarżonego nie narażało bezpieczeństwa Rzeszy Niemieckiej. Orzeczenia w ogóle nie podlegały zaskarżeniu za pomocą środków prawnych przysługujących oskarżonemu. Jedyną możliwością obalenia wyroku było niezatwierdzenie go przez rzeczowo wlaściwego dowódcę ${ }^{21}$. Szeroko zakreślono właściwość osobową sądów wojskowych; podlegali im mianowicie: żołnierze, urzędnicy wojskowi, marynarze, w szczególnych wypadkach rezerwiści, jeńcy wojenni, a także osoby cywilne oskarżone o szpiegostwo, udział w partyzantce, o wprowadzenie rozkładu do sił zbrojnych, o zdradę kraju i zdradę stanu, o uszkodzenie urządzeń wojskowych, wreszcie o wykroczenia przeciw zarządzeniom dowódcy wojskowego. Ponadto jurysdykcją wojskowego wymiaru sprawiedliwości objęto wszelkie przestępstwa popełnione w gmachach, zabudowaniach, urządzeniach i na okrętach shużących niemieckim siłom zbrojnym, a także przestępstwa mające miejsce na obszarze działá wojennych, bez względu na to, czy oskarżonym był Niemiec, czy cudzoziemiec.

Organami ferującymi orzeczenia były: wojskowe sądy polowe (Feldkriegsgerichte), wojskowe sądy pokładowe (Bordkriegsgerichte) dla marynarki wojennej (które z przyczyn oczywistych pomijam) i Sąd Wojenny Rzeszy (Reichskriegsgericht). Do składu sądzącego wojskowych sądów polowych wchodzily trzy osoby: wojskowy urzędnik sądowy jako przewodniczący

${ }^{20}$ A. W r z y z cz, Zarys organizacji sqdownictwa niemieckiego w Generalnym Gubernatorstwie w latach 1939-1945, „Zeszyty Majdanka” 1991, t. XIII, s. 5-6.

${ }^{21}$ L. Ter esiński, O dzialalności Sqdu Wojennego Rzeszy w okresie II wojny światowej, „Biuletyn GKBZH” 1972, t. XXIV, s. 176-182. 
i dwaj oficerowie sztabowi w stopniu wyższym niż oskarżony (jeden mógł być mu równy stopniem) jako ławnicy. W razie konieczności istniała możliwość rezygnacji $\mathrm{z}$ tych formalnych wymogów. Sąd Wojenny Rzeszy składał się z pięciu osób: prezesa senatu, sędziego Sądu Wojennego Rzeszy i trzech oficerów ${ }^{22}$.

Niemieckie sądownictwo wojskowe nie zostało zlikwidowane po utworzeniu GG; generalny gubernator Hans Frank zaaprobowal jego istnienie w rozporządzeniu o sądownictwie wojskowym w sprawach osób cywilnych z 26 stycznia 1940 r., które obowiązywało do końca okupacji ${ }^{23}$.

3.2. W dniu 12 września 1939 r. gen. Walter von Brauchitsch powołał wojskowe sądy doraźne. Funkcjonowały one na mocy rozporządzenia o posiadaniu broni, które uzupełniono aktami prawnymi o identycznej nazwie z 21 września i 6 października 1939 r., i działały na całych okupowanych przez Niemców ziemiach polskich. Rozporządzenie to dotyczyło nie tylko przestępstw związanych $\mathrm{z}$ posiadaniem broni, ale także wszelkich czynów skierowanych przeciwko armii niemieckiej bądź jej żołnierzom (przepis ten był sformułowany bardzo ogólnie, co dawało dużą swobodę interpretacji). W takich przypadkach orzekać miał nowo utworzony sąd doraźny wojskowy, w którego składzie zasiadal dowódca pułku (lub równorzędny mu pod względem uprawnień jurysdykcyjnych dowódca innej jednostki) i dwaj żołnierze. Jedyną przewidzianą w tym rozporządzeniu sankcją była kara śmierci, wykonana niezwłocznie. Wojskowe sądy doraźne działaly do 26 stycznia $1940 \mathrm{r}$. - tj. do czasu, kiedy ich zadania przejeło policyjne sądownictwo doraźne $\mathrm{GG}^{24}$.

3.3. Najkrócej funkcjonowały organy powołane 21 września 1939 r. rozporządzeniem uzupełniającym akt z 12 września 1939 r. o posiadaniu broni. Były to doraźne sądy tworzone przez policje niemiecką lub przez ,podgrupy operacyjne" SS, które wchodziły w skład szerszych struktur - grup operacyjnych SS (Einsatzgruppen der Sicherheitspolizei und der Sicherheitsdienstes). Ich zadaniem było utrzymywanie porządku i bezpieczeństwa na tyłach walczących armii niemieckich ${ }^{25}$. W ramach akcji przejmowania zarządu nad

${ }^{22}$ Ibidem, s. 180.

23 Prawo GG, C 110: Rozporządzenie z 26 I 1940 r. o sądownictwie wojskowym w sprawie osób cywilnych w GG, § 2. Inaczej sądzi Cz. Madajczyk, który uważa, że niemieckie sądy wojskowe działały w GG tylko do 26 I 1940 r. Cz. Madajczyk, Faszyzm i okupacje 1938-1945, t. I, Poznań 1984, s. 223.

${ }^{24}$ Prawo GG, C 300: Rozporządzenie Naczelnego Dowódcy Wojska z 12 IX 1939 r. o posiadaniu broni \& 1-4; C 301: Drugie rozporządzenie Naczelnego Dowódcy Wojska z 6 X 1939 r. dla uzupełnienia rozporządzenia o posiadaniu broni, §1; C $110, \S 4$.

${ }^{25}$ L. H e r zog, Grundzüge..., s. 124, 129; Okupacja i ruch oporu w dzienniku Hansa Franka 1939-1945, t. I, Warszawa 1970, s. 107; Cz. Łu cza k, Polityka ludnościowa i ekonomiczna hitlerowskich Niemiec w okupowanej Polsce, Poznań 1979, s. 102. 
krajem przez władze GG, grupy operacyjne zostały włączone w skład struktury organizacyjnej podległej wyższemu dowódcy SS i policji w Krakowie.

\subsection{W rozporządzeniu z 31 października 1939 r. wprowadzono jednolity} system policyjnego sądownictwa doraźnego $\mathbf{w} \mathbf{G G}^{26}$. Prawo powoływania tych sądów otrzymały niemiecka policja porządkowa i policja bezpieczeństwa. W składzie sądzącym jako przewodniczący zasiadal dowódca pułku lub komendant batalionu policji porządkowej, albo dowódca wydzielonego oddziału policji bezpieczeństwa, dwaj pozostali jej członkowie byli podwładnymi rekrutującymi się $\mathrm{z}$ tych jednostek. Tryb postępowania był bardzo uproszczony - wszystkie wymogi formalne zawarto w jednym krótkim paragrafie. Konieczne było mianowicie pisemne stwierdzenie nazwisk sędziów, skazanego i świadków, kwalifikacja czynu przestępnego, a także daty wydania $i$ wykonania wyroku. Zwraca uwage fakt, że ewentualny sprawca czynu nazywany jest skazanym, a nie oskarżonym, co dobitnie świadczy o intencjach władz. W rozporządzeniu tym (z 31 października 1939 r.) stworzono moźliwość przekazywania spraw sądownictwu specjalnemu, ale tylko w przypadku przewidywanych komplikacji lub zbyt rozbudowanego postępowania dowodowego. Sądom doraźnym podlegały następujące przestẹstwa: zamach skierowany przeciwko III Rzeszy lub władzom GG, uszkodzenie urządzeń niemieckich lub urządzeń użyteczności publicznej, agitacja do nieposłuszeństwa wobec zarządzeń władz niemieckich, czyn gwaltu skierowany przeciwko Niemcowi $\mathrm{z}$ powodu jego narodowości, umyślne podpalenie powodujące szkodę w majątku Niemca. Jedyną sankcją przewidzianą $w$ tym rozporządzeniu była kara śmierci orzekana także w przypadku usiłowania popelnienia czynu. Podlegali jej też pomocnicy, podżegacze, a nawet osoby, które nie doniosły władzom policyjnym o planowanym przez kogoś innego przestępstwie ${ }^{27}$.

Drogą obalenia wyroku policyjnego sądu doraźnego była wyłącznie interwencja generalnego gubernatora, który mógł zastosować prawo laski lub polecić sprawdzenie budzącego wątpliwości rozstrzygnięcia. Te dwie instytucje prawne wymagają szerszego omówienia, ponieważ na ich przykładzie można dokładnie zaobserwować dobrze znane kontrowersje między kierownictwem Generalnego Gubernatorstwa (Frank i jego najbliżsi współpracownicy) a dowództwem SS i policji, które nie chciało się podporządkować władzom w Krakowie ${ }^{28}$. Zgodnie z powoływanym rozporządzeniem z 31 października 1939 r. generalny gubernator mógł polecić, aby niesłuszny jego zdaniem wyrok policyjnego sądu doraźnego zostal sprawdzony przez wyższego

\footnotetext{
${ }^{26}$ Prawo GG, C 305: Rozporządzenie z 31 X 1939 r. celem zwalczania czynów gwałtu w GG.

27 Prawo GG, C 305, \& 1-10, 12.

${ }^{28} \mathrm{Cz} . \mathrm{Madajczyk}$, Polityka..., t. I, s. $148-165$.
} 
dowódce SS i policji. Jego uprawnienia nie były zatem zbyt duże, bowiem nie miał żadnego wpływu na treść końcowego rozstrzygnięcia. Sytuacja zmieniła się po wydaniu przez Hitlera dekretu z 30 stycznia 1940 r. o stosowaniu prawa laski na okupowanych obszarach polskich ${ }^{29}$. Na mocy tego dekretu Frank otrzymal prawo do podejmowania decyzji w sprawach ułaskawień oraz prawo do umarzania postępowania. Przez następne miesiące starał się, aby te przepisy były rzeczywiście realizowane. Próbował to osiągnąć różnymi metodami: na drodze ustawodawczej, w formie nakazów skierowanych bezpośrednio do nadzorujących formalnie policję urzędników administracji, a także domagając się dostarczania mu akt w sprawach budzących wątpliwości ${ }^{30}$.

Wymienione przeze mnie w pkt. 3.2, 3.3 i 3.4 niemieckie organy trudno nazwać sądami w pełnym tego słowa znaczeniu; funkcjonowały one bowiem $\mathrm{z}$ pogwałceniem elementarnych zasad nowożytnego procesu karnego. W tej sytuacji jedynymi niemieckimi organami wymiaru sprawiedliwości, które zapewniały minimum gwarancji procesowych w GG w pierwszych miesiącach okupacji, byly sądy specjalne.

3.5. W okresie przedwojennym w III Rzeszy najskuteczniejszym instrumentem stosowanym przez hitlerowców do walki z przejawami opozycji politycznej były sądy specjalne, powołane w Niemczech rozporządzeniem Rządu Rzeszy z 21 marca 1933 r. Do ich kompetencji należało przede wszystkim rozpoznawanie spraw o charakterze politycznym, ale jeszcze w okresie przedwojennym kompetencje te $\mathrm{w}$ praktyce znacznie rozszerzono ${ }^{31}$. Na ziemiach polskich w czasie wojny podstawą funkcjonowania niemieckich sądów specjalnych było rozporządzenie naczelnego dowódcy wojsk lądowych Waltera Brauchitscha z 5 września 1939 r. Stosowały one niemieckie prawo karne i podlegały nadzorowi shuzbowemu ministra sprawiedliwości III Rzeszy. Po okrzepnięciu władzy okupanta organizowano je sukcesywnie w większych polskich miastach. Na terenach późniejszego GG, już w pierwszej połowie września funkcjonowały one w Częstochowie, Wieluniu i Krakowie, a nieco później w Piotrkowie (po przeniesieniu z Wielunia), Kielcach i Radomiu ${ }^{32}$. W trakcie działań wojennych pojawily się kontrowersje co do rozdziału kompetencji między sądy wojskowe i sądy specjalne. Obowiązywała zasada, że wszelkie czyny zabronione popełnione na obszarze działań armii niemieckiej,

${ }^{29}$ Prawo GG, C 390: Dekret Führera i kanclerza Rzeszy Niemieckiej z 30 I 1940 r. o stosowaniu prawa łaski na okupowanych obszarach polskich.

${ }^{30}$ Prawo GG, C 395: Dekret z 28 III 1940 r. o stosowaniu prawa laski w GG; Okupacja..., t. I, s. $153,172-173$.

${ }^{31}$ RGBI I, s. 136-138, 259; E. Zarzycki, Eksterminacyjna..., s. 13-14.

${ }^{32}$ G. Moritz, Gerichtsbarkeit in den von Deutschland besetzen Gebieten 1939-1945, Tübingen 1957, s. 58; E. Zarzy cki, Eksterminacyjna..., s. 16-17. 
podlegają sądownictwu wojskowemu, a sądy specjalne mogą rozpoznawać tylko te konkretne sprawy, które zostały im przekazane przez władze wojskowe. Administracja wojskowego wymiaru sprawiedliwości zalecala sądom wojskowym oddawanie sądownictwu specjalnemu tych przypadków, które nie godzą bezpośrednio $\mathrm{w}$ bezpieczeństwo Wehrmachtu. Postulaty wyplywające $\mathrm{z}$ sądów specjalnych szły jeszcze dalej. Rozważano przekazanie sądownictwu specjalnemu wszelkich czynów zabronionych, popelnianych na obszarze tyłowym, bez konieczności powiadamiania organów wojskowego wymiaru sprawiedliwości, z wyjątkiem działań partyzanckich i szpiegostwa ${ }^{33}$.

3.6. W dniu 15 listopada 1939 r. generalny gubernator wydal rozporządzenie, w którym nakazał istniejącym na terenie GG sądom specjalnym w dalszym ciągu wykonywać swoje funkcje, ale już jako sądom specjalnym w GG, jeśli urzędowały w stolicy dystryktu (Kraków, Lublin, Radom, Warszawa), lub jako wydziałom sądu specjalnego, jeśli działały w innych miejscowościach (Częstochowa, Kielce, Piotrków, Rzeszów, Zamość) ${ }^{34}$. Sądy specjalne orzekały na podstawie niemieckiego prawa karnego w sprawach, które zostały im wyraźnie przekazane konkretnym rozporządzeniem. Poza tym rozstrzygały przypadki szczególnie ciężkich przestępstw, przy czym kwalifikacji i decyzji o wlaściwości sądu dokonywała tu prokuratura. Sprawa, która zawisła przed sądem specjalnym, nie mogła być przekazana do postępowania zwyczajnego. Skład sądzący tworzyło trzech sędziów; w sprawach niezawilych, na wniosek prokuratury, możliwe było rozstrzyganie jednoosobowe. Postępowanie było jednoinstancyjne i nie przewidziano możliwości zastosowania środków odwoławczych. Wyznaczenie obrońcy zależało od dobrej woli sądu. Możliwe było wydawanie nakazów karnych, na mocy których ławnicy sądów specjalnych mogli wymierzać kary do jednego roku więzienia. Od tego orzeczenia przyshugiwal sprzeciw, w terminie dwóch tygodni, rozpatrywany ostatecznie przez sąd ${ }^{35}$. Jedynymi możliwościami wzruszenia wyroków były: skorzystanie $z$ prawa laski przez generalnego gubernatora Hansa Franka lub sprzeciw nadzwyczajny kierownika głównego wydziału sprawiedliwości. $\mathrm{O}$ znaczeniu sądów decydowały: usytuowanie blisko nich $\mathrm{i}$ funkcjonalny $\mathrm{z}$ nimi związek prokuratury (Staatsanwaltschaft; początkowo używano

${ }^{33}$ APL, SSpP, sygn. 1, k. 4, 7.

${ }^{34} \mathrm{Cz}$. M ad ajczy k, Polityka..., t. II, s. 246; Prawo GG, C 105: Rozporządzenie z $15 \mathrm{XI}$ 1939 r. o sądach specjalnych w GG, § 1, 10. Warto zwrócić uwagę, że w powolywanym rozporządzeniu, wydrukowanym w języku polskim, używana jest nazwa „sądy wyjątkowe” dla oznaczenia organów funkcjonujących od 5 IX do 15 XI 1939 r. W grudniu $1940 \mathrm{r}$. przeniesiono siedzibę sądu specjalnego $w$ dystrykcie lubelskim $z$ Zamościa do Chełma. BB, R 52 III, Wydział Główny Spraw Wewnętrznych w Rządzie GG - Hauptabteilung Innere Verwaltung der Regierung des Generalgouvernements, sygn. 17, k. 65 .

${ }_{35}$ Prawo GG, C 105: § 2-9; G. Moritz, Gerichtsbarkeit..., s. 62-63, 66; F. R yszka, Państwo stanu wyjatkowego, Wrocław 1985, s. 391-392. 
urzędowej nazwy Anklagebehörde), która obsługiwała od strony prawnej sądy niemieckie i wyższe sądy niemieckie oraz decydowała o ewentualnym przekazaniu niektórych spraw karnych sądownictwu polskiemu. W sumie więc wszystkie czyny, które nie interesowały sądów policyjnych i wojskowych, były ścigane przez ten organ ${ }^{36}$.

Do 24 października 1939 r. w Sądzie Specjalnym w Częstochowie załatwiono 15 spraw, a dziesięć czekało na rozpatrzenie; do Sądu Specjalnego w Piotrkowie wplynęło 165 spraw, z których załatwiono około 10\%; w Sądzie Specjalnym w Kielcach zarejestrowano 95 spraw, z czego zakończono 19; do Sądu Specjalnego w Krakowie wpłynęły 163 sprawy, z których załatwiono zaledwie 13 (ministerstwo sprawiedliwości uznało za konieczne zwiększyć obsadę tamtejszej prokuratury); do Sądu Specjalnego w Radomiu wpłynęło 67 spraw. W ocenie ministerstwa sprawiedliwości Rzeszy sprawy rozpatrywane na polskich terenach okupowanych nie byly typowe dla dotychczasowego zakresu kompetencji sądownictwa specjalnego w Niemczech. Przeważały bowiem ciężkie przestępstwa pospolite, leżące $w$ gestii sądownictwa zwykłego, ale rozpatrywały je sądy specjalne, gdyż systemu sądownictwa powszechnego jeszcze nie uruchomiono ${ }^{37}$. Działalność sądów i prokuratur w GG (lub na terenach przyszlego GG) w okresie do 30 listopada 1939 r. przedstawiają tabele 1 i 2 .

Warto podkreślić, że sądy specjalne już od września 1939 r., obok funkcji jurysdykcyjnej, spełniały także inne zadania powierzone przez władze okupacyjne. Na uwage zashugują zwlaszcza prace przygotowawcze do uruchomienia pełnego systemu sądownictwa prowadzone przez organy administracji wymiaru sprawiedliwości w ramach zarządu wojskowego, w których wykorzystywano potencjał kadrowy sądów specjalnych. Sędziowie sądów specjalnych już we wrześniu $1939 \mathrm{r}$. obarczeni zostali obowiązkiem organizowania cywilnego wymiaru sprawiedliwości, a w szczególności - uruchamiania sądownictwa niespornego. Polecono im kontrolę nad polskimi sądami, notariuszami i adwokaturą oraz zabezpieczenie wszelkich akt i dokumentów sądowych i notarialnych. Obarczenie wykonywaniem czynności - obok orzekania w sądzie specjalnym - spowodowało domaganie się o oddelegowanie dodatkowych sędziów, bądź wyznaczenie specjalnego pelnomocnika, który organizowałby cywilny wymiar sprawiedliwości. Przewodniczący sądów specjalnych skarżyli się także na poważne klopoty komunikacyjne. Utrudniające - wobec braku samochodów do wyłącznej ich dyspozycji - poruszanie się po terenie niedawnych działań wojennych, w celu tworzenia sądownictwa cywilnego lub niezbędnych kontaktów $\mathrm{z}$ sąsiadującymi terytorialnie sądami specjalnymi ${ }^{38}$.

\footnotetext{
${ }^{36}$ Prawo GG, C 120: § 3; C 150, § 1 .

${ }^{37}$ BB, R 3001, sygn. 9803/7/1, k. 56.

${ }^{38}$ APŁ, SSpP, sygn. 1, k. 2, 3, 14, 15, 22, 23.
} 
Tabela 1: Działalnośc prokuratur i sądów specjalnych w Generalnym Gubernatorstwie (lub na terenie przyszłego GG) do 15 listopada 1939 r. (Według: BB, R 3001, sygn. 98/7/2, k. 17-18)

\begin{tabular}{|c|c|c|c|c|c|c|c|c|c|c|c|c|c|c|c|c|c|}
\hline \multirow{3}{*}{$\begin{array}{l}\text { Prokuratura } \\
\text { i sad specjalny }\end{array}$} & \multirow{3}{*}{ 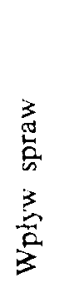 } & \multicolumn{5}{|c|}{ Załatwiono spraw } & \multirow{3}{*}{ 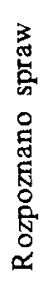 } & \multicolumn{8}{|c|}{ Rodzaje wymierzonych kar } & \multirow{2}{*}{\multicolumn{2}{|c|}{$\begin{array}{l}\text { Uniewin- } \\
\text { niono }\end{array}$}} \\
\hline & & \multirow{2}{*}{ 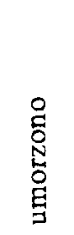 } & \multirow{2}{*}{ 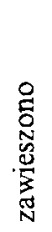 } & \multirow{2}{*}{ 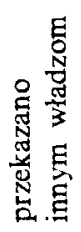 } & \multirow{2}{*}{ 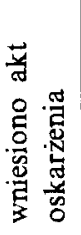 } & \multirow{2}{*}{$\begin{array}{l}0 \\
0 \\
0 \\
0 \\
0 \\
0 \\
\text { 总 }\end{array}$} & & \multicolumn{2}{|c|}{$\begin{array}{c}\text { kara } \\
\text { śmierci }\end{array}$} & \multicolumn{2}{|c|}{$\begin{array}{c}\text { dożywotnie } \\
\text { ciężkie } \\
\text { więzienie }\end{array}$} & \multicolumn{2}{|c|}{$\begin{array}{l}\text { ciężkie } \\
\text { więzienie }\end{array}$} & \multicolumn{2}{|c|}{ więzienic } & & \\
\hline & & & & & & & & $\mathbf{M}$ & K & $\mathbf{M}$ & $\mathrm{K}$ & $\mathbf{M}$ & $\mathrm{K}$ & M & $\mathrm{K}$ & M & $\mathrm{K}^{\prime}$ \\
\hline Częstochowa & 168 & 67 & 1 & 18 & 38 & 1 & 28 & - & - & - & - & 12 & - & 30 & 6 & 4 & 2 \\
\hline Kielce & 134 & 36 & - & 29 & 34 & 5 & 29 & - & - & - & - & 5 & - & 29 & 5 & 2 & $\cdots$ \\
\hline Krakow & 853 & 241 & 5 & 208 & 87 & 3 & 38 & - & - & - & - & 11 & - & 25 & 8 & 6 & 3 \\
\hline Piolrków Tryb. & 259 & 82 & 5 & 12 & 39 & - & 34 & - & - & - & - & 7 & - & 34 & 3 & 5 & 1 \\
\hline Radom & 201 & 70 & - & 17 & 25 & - & 14 & - & - & - & - & - & - & 14 & 2 & 3 & - \\
\hline
\end{tabular}

$\mathbf{K}=$ kobieta; $\mathbf{M}=$ mężczyzna . 
Tabela 2: Działalność prokuratur i sądów specjalnych w Generalnym Gubernatorstwie w okresie 15-30 listopada 1939 r. (Według: BB, R 3001, sygn. 98/7/2, k. 125)

\begin{tabular}{|c|c|c|c|c|c|c|c|c|c|c|c|c|c|c|c|c|c|}
\hline \multirow{3}{*}{$\begin{array}{l}\text { Prokuratura } \\
\mathrm{i} \text { sąd specjalny }\end{array}$} & \multirow{3}{*}{ 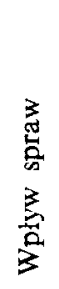 } & \multicolumn{5}{|c|}{ Załatwiono spraw } & \multirow{3}{*}{ 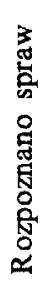 } & \multicolumn{8}{|c|}{ Rodzaje wymierzonych kar } & \multirow{2}{*}{\multicolumn{2}{|c|}{$\begin{array}{l}\text { Uniewin- } \\
\text { niono }\end{array}$}} \\
\hline & & \multirow{2}{*}{$\begin{array}{l}\stackrel{0}{0} \\
\text { 옹 } \\
\text { 怘 }\end{array}$} & \multirow{2}{*}{ 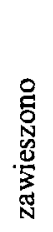 } & \multirow{2}{*}{ 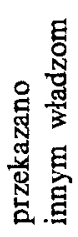 } & \multirow{2}{*}{ 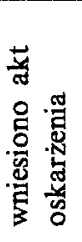 } & \multirow{2}{*}{ 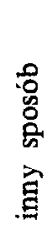 } & & \multicolumn{2}{|c|}{$\begin{array}{c}\text { kara } \\
\text { śmierci }\end{array}$} & \multicolumn{2}{|c|}{$\begin{array}{c}\text { dożywotnie } \\
\text { ciężkie } \\
\text { więzienie }\end{array}$} & \multicolumn{2}{|c|}{$\begin{array}{c}\text { ciężkie } \\
\text { więzienie }\end{array}$} & \multicolumn{2}{|c|}{ więzienie } & & \\
\hline & & & & & & & & $\mathbf{M}$ & $\mathbf{K}$ & $\mathbf{M}$ & $\mathrm{K}$ & $\mathbf{M}$ & $\mathbf{K}$ & $\mathbf{M}$ & K & M & $\mathrm{K}$ \\
\hline Częstochowa & 80 & 32 & 1 & 29 & 14 & - & 14 & - & - & - & - & 6 & - & 20 & 3 & - & 1 \\
\hline Kielce & 60 & 8 & - & 20 & 13 & - & 15 & - & - & - & - & - & - & 29 & 2 & 1 & - \\
\hline Piotrkow Tryb.* & 96 & 38 & 3 & 3 & 17 & - & 11 & - & - & - & - & 1 & - & 9 & 1 & 2 & 1 \\
\hline Radom & 77 & 11 & - & 38 & 13 & 2 & 8 & - & - & - & - & - & - & 14 & 2 & 1 & - \\
\hline
\end{tabular}

$\mathbf{K}=$ kobieta; $\mathbf{M}=$ mężczyzna. * Do Sądu Specjalnego w Piotrkowie Trybunalskim wpłynęło do 5 grudnia 1939 r. ogółem 355 spraw. E. Zarzycki, (Eksterminacja i dyskryminacyjna dzialalnośc hitlerowskich sqdów okregu Gdańsk - Prusy Zachodnie w latach 1939-1945, Bydgoszcz 1981, s. 21), J. Góral i M. Uzdowski (Hitlerowski Sqd Specjalny w Piotrkowie Trybunalskim. Zarys dzialalności, [w:] Materialy z sesji naukowej: Okupacja hitlerowska w Piotrkowskiem, red. J. Góral, Piotrków 1998, s. 46) podają, że w grudniu 1939 r. liczba ta zwiększyła się do 535 . 
4. Wydane jednocześnie $w$ dniu 19 lutego 1940 r. dwa rozporządzenia o sądownictwie niemieckim i o sądownictwie polskim stanowiły realizacje idei dualistycznego systemu wymiaru sprawiedliwości w GG. W ciągu kilku następnych miesięcy wprowadzano w życie te rozporządzenia $\mathrm{i}$ organizowano pełny okupacyjny system wymiaru sprawiedliwości w GG obejmujący sądy, prokuraturę, adwokaturę, notariat $\mathrm{i}$ więziennictwo.

4.1. W obrębie niemieckiego pionu wymiaru sprawiedliwości ustanowione zostały sądy niemieckie i wyższe sądy niemieckie, które stanowily sądownictwo powszechne dla osób posiadających niemiecką przynależność państwową lub osób narodowości niemieckiej. W porównaniu do struktury sądów powszechnych w Rzeszy było to sądownictwo bardzo uproszczone. Przede wszystkim sądy te pozostawały poza głównym nurtem wymiaru sprawiedliwości karnej i w glównej mierze rozpatrywały sprawy cywilne, które w ówczesnej wojennej rzeczywistości miały, siłą rzeczy, znaczenie mniejsze niż zwykle. W praktyce zaczęły funkcjonować dopiero na początku kwietnia 1940 r.; uroczystego otwarcia sądownictwa niemieckiego dokonał generalny gubernator Hans Frank w Krakowie 9 kwietnia $^{39}$.

W pierwszej instancji orzekały jednoosobowo sądy niemieckie utworzone w wyznaczonych miejscowościach: Krakowie, Rzeszowie, Lublinie, Chełmie, Radomiu, Piotrkowie, Warszawie i Żyrardowie. O granicach ich działania decydował szef dystryktu, na terenie którego miały one swoją siedzibę. Drugą instancją były wyższe sądy niemieckie, powolane w stolicy każdego dystryktu, orzekające w składzie trzech sędziów ${ }^{40}$.

Fakt pozostawania powszechnych sądów niemieckich poza głównym nurtem wymiaru sprawiedliwości karnej posiada pośrednio swe źródło w przepisach ich dotyczących. Według tych przepisów, niemieckiemu sądownictwu karnemu podlegali obywatele III Rzeszy i osoby narodowości niemieckiej będące obywatelami innych krajów oraz nie-Niemcy, jeśli popełnili następujące czyny:

„1) skierowane przeciw bezpieczeństwu i autorytetowi Rzeszy Niemieckiej i narodu niemieckiego, przeciwko jego interesom oraz przeciw życiu, zdrowiu, czci i majątkowi osób posiadających niemiecką przynależność państwową lub narodowości niemieckiej;

2) zagrożone są karą $w$ rozporządzeniach generalnego gubernatora lub urzędów przezeń upoważnionych;

${ }^{39}$ BB, R 52 II, Kancelaria Generalnego Gubernatora - Kanzlei des Generalgouverneurs, sygn. 262, k. 277, 280, 283. Uroczyste otwarcie Wyższego Sądu Niemieckiego w Radomiu nastąpiło dopiero $25 \mathrm{~V} 1940 \mathrm{r}$. W Warszawie sądownictwo niemieckie zostało uruchomione 11 IV 1940 r. W. Bartoszewski, 1859 dni Warszawy, Kraków 1983, s. 67; A. W r z s zcz, Zarys..., s. 15-16.

${ }^{40}$ Prawo GG, C 120, § 1, 2. 
3) popełnione zostały w budynku, pomieszczeniu lub zakładzie służącym celom władzy niemieckiej;

4) popełnione zostały w służbie zarządu niemieckiego lub w związku z tą służbą"4l.

Dotyczyło to także wspólsprawców, popleczników, uczestników i paserów. W pierwszej instancji rozstrzygał sąd niemiecki; od jego orzeczeń przysługiwały apelacje i zażalenia do wyższego sądu niemieckiego, które musiały być złożone $w$ terminie dwutygodniowym. Rozstrzygnięcia wyższego sądu niemieckiego były ostateczne, natomiast wszczęcie postępowania karnego było możliwe tylko $\mathrm{z}$ oskarżenia publicznego, ale obecność przedstawiciela prokuratury na rozprawie głównej przed sądem niemieckim nie była konieczna. O potrzebie powołania obrońcy decydował sąd ${ }^{42}$. Przepisy dotyczące karnego wymiaru sprawiedliwości przed sądami niemieckimi i wyższymi sądami niemieckimi były wśród dotychczas omówionych uregulowań niewątpliwie najkorzystniejsze dla oskarżonych. Ich znaczenie osłabial jednak fakt przejmowania poważnych $-\mathrm{z}$ punktu widzenia okupanta - przestępstw przez sądy specjalne lub przez sądy doraźne, działające na podstawie własnych, szeroko zakreślonych kompetencji.

W zakresie prawa cywilnego sądownictwu niemieckiemu podlegały sprawy, w których jedną ze stron lub uczestnikiem postępowania była osoba posiadająca niemiecką przynależność państwową albo osoba narodowości niemieckiej. Bardzo dokładnie określono osoby prawne $i$ inne organizacje nie posiadające osobowości prawnej, które należało uważać za podmioty niemieckie ${ }^{43}$. Jurysdykcja sądu obejmowała:

„1) sprawy cywilne (włącznie $z$ tymczasowymi zarządzeniami) gdy tylko jeden podmiot posiadający niemiecką przynależność państwową lub przynależny do narodu niemieckiego występuje $w$ tej sprawie jako strona lub interwenient uboczny;

2) sprawy egzekucyjne, gdy zobowiązany posiada niemiecką przynależność państwową lub jest przynależny do narodu niemieckiego, lub gdy chodzi o egzekucję $\mathrm{z}$ tytulu wydanego przez sąd niemiecki lub sporządzonego przed notariuszem niemieckim;

3) sprawy upadłościowe i ugodowe, jeśli dłużnik upadłościowy lub dłużnik, który wniósł o postępowanie ugodowe, posiada niemiecką przynależność państwową lub jest przynależny do narodu niemieckiego;

4) sprawy sạdownictwa niespornego, jeżeli według przepisów obowiązujących w Altreich dla mającego być zastosowanym prawa, miarodajna jest

\footnotetext{
4 Prawo GG, C 120, \& 7.

42 Prawo GG, C 120, $\S 8-10,12,13,15$.

43 Prawo GG, C 120, 20.
} 
przynależność państwowa danej osoby, a ta osoba posiada niemiecką przynależność państwową lub jest przynależną do narodu niemieckiego; 5) prowadzenie niemieckich rejestrów handlowych".

Apelacje i zażalenia wniesione od orzeczeń sądu niemieckiego w pierwszej instancji rozstrzygał wyższy sąd niemiecki jako druga instancja. Przymus adwokacki nie istniał. Odwoławczym środkiem nadzwyczajnym był sprzeciw nadzwyczajny, który wzruszał prawomocne wyroki wydane zarówno w pierwszej, jak i w drugiej instancji. Wnosić go mógł kierownik głównego wydziału sprawiedliwości w ciągu sześciu miesięcy od uprawomocnienia się, jeśli wyrok budził bardzo poważne wątpliwości. W sprawach cywilnych sprzeciw rozstrzygał wyższy sąd niemiecki, wyznaczony przez kierownika głównego wydziału sprawiedliwości, a w sprawach karnych - sąd specjalny ${ }^{44}$.

W dniu 1 lipca 1940 r. w sądach niemieckich, wyższych sądach niemieckich, sądach specjalnych, prokuraturze i w wydziałach sprawiedliwości w całym GG zatrudnionych było: 95 sędziów i prokuratorów, 39 urzędników wyższej rangi, 13 urzędników średniego szczebla, czterech wachmistrzów, 60 oddelegowanych pracowników oraz 83 innych pracowników ${ }^{45}$. Do prokuratury niemieckiej wpłynęło do końca czerwca 1940 r. aż 43968 spraw. W tym samym czasie $w$ ramach sądownictwa niemieckiego rozstrzygnięto $w$ formic wyroków lub nakazów karnych 4128 spraw. W obrębie cywilnego wymiaru sprawiedliwości statystyka ta przedstawiała się następująco: 1481 spraw z zakresu sądownictwa spornego, 395 spraw z zakresu sądownictwa niespornego, 3130 innych spraw o charakterze ogólnym (a w szczególności z zakresu pomocy prawnej i uwierzytelnień $)^{46}$.

Obsługe prawną omówionych wyżej sądów specjalnych, sądów niemieckich i wyższych sądów niemieckich zapewniali adwokaci i notariusze niemieccy. Zawód adwokacki mogli wykonywać wszyscy, którym przysługiwały takie uprawnienia w Rzeszy Niemieckiej, oraz adwokaci pochodzenia niemieckiego, dopuszczeni do spelniania tych funkcji w GG. Do wykonywania praktyki adwokackiej niezbędne było zezwolenie kierownika głównego wydziału sprawiedliwości. Dotyczyło ono otwarcia kancelarii w jednej, określonej miejscowości i mogło być opatrzone warunkiem występowania tylko przed oznaczonym sądem. Adwokaci musieli prowadzić sprawy osobiście $i$ nie mogli równolegle wykonywać praktyki w Rzeszy; podlegali oni nadzorowi kierownika wydziału sprawiedliwości przy urzędzie gubernatora dystryktu ${ }^{47}$.

4 Prawo GG, C 120, § 19-32.

45 BB, R 52 II, sygn. 247, k. 52.

${ }_{46} \mathrm{BB}, \mathrm{R} 52 \mathrm{II}$, sygn. 247, k. $47,52$.

47 Prawo GG, C 120, \& 4; C 135: Rozporządzenie z 13 IX 1940 r. o niemieckich adwokatach w GG, $§ 1-4 ;$ L. WoIf gram , Deutsche Rechtsanwäle und deutsche Notare im Generalgouvernement, „Deutsches Recht” 1942, H. 43/44, s. 1428-1429. Prawo do występowania przed sądami niemieckimi uzyskiwali też niekiedy polscy adwokaci. W. B a y e r, Konspiracyjna 
$\mathrm{Z}$ adwokaturą niemiecka ściśle powiązana była instytucja notariatu, którą uruchomiono jednak z dużym opóźnieniem, bo dopiero pod koniec $1941 \mathrm{r}$. $\mathrm{Na}$ stanowiska notariuszy mogli być powoływani tylko adwokaci niemieccy, którym zezwolono na otwarcie kancelarii w GG. Skladali oni odpowiednią przysięge i podlegali nadzorowi służbowemu kierownika wyższego sądu niemieckiego. Waściwość notariatu niemieckiego zawierała się w obrębie sądownictwa niemieckiego. W zakresie kompetencji sądownictwa polskiego przewidziano możliwość działania niemieckich notariuszy tylko w przypadku, gdy w czynności prawnej będącej przedmiotem aktu notarialnego bral udzial obywatel Niemiec lub osoba pochodzenia niemieckiego (albo jeśli $\mathrm{z}$ tej czynności nabywały one prawo). Siedzibami urzędowymi niemieckich notariuszy były miasta, w których dozwolono im wykonywać zawód adwokata, a właściwość miejscowa była ograniczona do terytorium dystryktu ${ }^{48}$.

4.2. Struktura organizacyjna okupacyjnego sądownictwa polskiego została mocno okrojona $\mathrm{w}$ porównaniu $\mathrm{z}$ okresem przedwojennym. Zawieszono działalność Sądu Najwyższego. Niektóre jego kompetencje przekazano kierownikowi głównego wydziału sprawiedliwości, a inne zniesiono ${ }^{49}$. Postępowanie było dwuinstancyjne; istnialy sądy grodzkie, okręgowe i apelacyjne. Zlikwidowano natomiast sądy pracy, przekazując ich kompetencje sądom grodzkim, a także zniesiono sądownictwo administracyjne. Ponadto zreorganizowano urzędy hipoteczne, w których dotychczasową obsadę składającą się z pisarzy hipotecznych zastąpiono sędziami grodzkimi. O wpływających wnioskach rozstrzygał $\mathrm{w}$ pierwszej instancji jednoosobowo sędzia grodzki, a w drugiej instancji wyrokował sąd grodzki i było to orzeczenie ostateczne.

W poszczególnych ośrodkach organizowano sądy i prokuraturę w różnych terminach. Regułą było uruchamianie w pierwszej kolejności sądów grodzkich, a później - sądów wyższych instancji ${ }^{50}$. Sądy apelacyjne działały w stolicach

organizacja i dzialalność adwokatury polskiej w okresie okupacji hitlerowskiej, „Palestra” 1983, nr 8, s. 23-24; A. Wrzyszcz, Z dzialalności Sqdu Specjalnego w Radomiu (1939-1945), „Czasopismo Prawno-Historyczne” 2001, t. LIII, z. 1, s. 341.

${ }^{48}$ Rozporządzenie o niemieckich notariuszach w Generalnym Gubernatorstwie z 17 XII 1941 r., Dziennik Rozporządzeń Generalnego Gubernatorstwa 1941, s. 731-732; A. W r z y s z c z, Notariat w Generalnym Gubernatorstwie (1939-1945) - stan prawny, „Rejent” 1997, R. 7, nr 11, s. $165-167$.

49 Prawo GG, C 150, § 5. Kierownik głównego wydziału sprawiedliwości rozstrzygał spory co do właściwości polskich sądów.

${ }^{50}$ W Warszawie: sądy grodzkie - 11 XII 1939 r., a okręgowe - 18 XII 1939 r; W. Bartoszewski, 1859 dni..., s. 92; W Kraśniku sąd grodzki - ok. 20 I 1940 r.; Z. M ańk owski, Pierwsze miesiqce okupacji niemieckiej w Kraśniku (październik 1939 - maj 1940), [w:] $W$ kregu polskich doświadczeń historycznych $X I X$ i $X X$ w., Lublin 1986, s. 179; W Lublinie akcja ta trwała od początku stycznia do 8 IV 1940 r.; J. M a zurkiewicz, L. Policha, Dzieje sqdownictwa lubelskiego w latach 1915-1944, mpis, s. 46. 
dystryktów. Aby zrealizować te postanowienia, utworzono nowy Sąd Apelacyjny $w$ Radomiu, przekazując mu od razu sprawy $z$ tego dystryktu zawisłe już w sądach apelacyjnych w Warszawie, Krakowie i Lublinie, oprócz przypadków wyjątkowych uzasadnionych względami celowościowymi ${ }^{31}$. W pozostałych ośrodkach reaktywowano istniejące tam już przed wojną apelacje.

$\mathrm{O}$ potrzebie ponownego uruchomienia sądów okręgowych decydował gubernator dystryktu, na terenie którego miały one swoją siedzibę. On też wyznaczal, w związku ze zmianą granic administracyjnych, nowe obszary ich funkcjonowania. W dniu 1 lipca 1940 r. w dystrykcie krakowskim funkcjonowało pięć sądów okręgowych: w Jaśle (z ośrodkiem zamiejscowym w Sanoku), w Krakowie, Nowym Sączu, Rzeszowie i Tarnowie, oraz 75 sądów grodzkich. W dystrykcie lubelskim działały dwa sądy okręgowe: w Lublinie i Zamościu, i 24 sądy grodzkie. W dystrykcie radomskim uruchomiono trzy sądy okręgowe: w Kielcach, Piotrkowie (z ośrodkiem zamiejscowym w Częstochowie) i w Radomiu, oraz 35 sądów grodzkich. W dystrykcie warszawskim funkcjonowały dwa sądy okręgowe: w Siedlcach

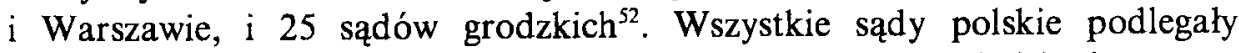
bezpośredniemu nadzorowi gubernatorów dystryktu. Sędziowie i inni pracownicy zostali ponownie zatrudnieni, lecz musieli złożyć pisemną deklarację posłuszeństwa i lojalności wobec administracji niemieckiej. Zachowano urzędowy strój sędziów, ale usunięto lańcuchy, na których znajdowało się godło Państwa Polskiego. Z tego samego powodu zmieniono dotychczasowe pieczęcie. Uchylono prawo sędziów do ferii sądowych. Sądy rozpoznawały $\mathrm{w}$ składach przewidzianych $\mathrm{w}$ polskich przepisach. Modyfikacją było wykluczenie sędziów niezawodowych. Wszystkie odniesienia kodeksowe procedury karnej i cywilnej wskazujące na właściwość sądów warszawskich zniesiono, zastępując je identycznymi skierowaniami do sądów krakowskich. Sędziowie polscy zostali pozbawieni możliwości warunkowego zawieszania kar. Wyroki wydawano z formulką „w imieniu prawa”. Wobec zawieszenia działalności Sądu Najwyższego nie istniała możliwość kasacji i w związku z tym jedynymi dopuszczalnymi środkami odwoławczymi były zażalenia i odwołania. Rozpatrywały je w drugiej instancji sądy okręgowe (jeśli pierwszą instancją był sąd grodzki) i sądy apelacyjne. Ich rozstrzygnięcia były ostateczne ${ }^{53}$.

Przepisy prawa materialnego, na podstawie których wydawano wyroki, były przepisami prawa polskiego. Prawo to obowiązywało, o ile nie pozostawało $w$ sprzeczności $z$ przejęciem władzy przez Rzeszę Niemiecką

${ }^{51}$ Prawo GG, C 151: Postanowienie wykonawcze z 1 VIII 1940 r. do rozporządzenia z 19 II 1940 r. o sądownictwie polskim w GG, pkt 5 i C $150 \S 5,7,11,13$.

52 BB, R 52 II, sygn. 247, k. 54.

${ }_{53}$ Prawo GG, C 150, § 4, 6, 11, 13 i C 175; Rozporządzenie z 22 VI 1940 r. w sprawie uchylenia ferii sądowych $w$ sądownictwie polskim; M. Sworzeń, Sqdownictwo polskie w Generalnym Gubernatorstwie, „Prawo i Życie" 1987, nr 40, s. 10. 
i wykonywaniem wojskowych praw zwierzchnich. W praktyce uchylono przepisy polskiego prawa państwowego, administracyjnego, finansowego, pracy, wojskowego i osadniczego. Zachowano więc prawo karne i cywilne, materialne i procesowe, ale poddawano je często istotnym zmianom. Uprawnienia do takich zmian i do tworzenia nowych aktów prawnych $w$ innych dziedzinach miał kanclerz $\mathrm{i}$ upoważnione przez niego organy centralne Rzeszy, a także generalny gubernator oraz dowódca SS i policji w GG. Uregulowania te były wyraźnie niezgodne $z$ prawem międzynarodowym ${ }^{54}$.

Sądy polskie były właściwe dla rozstrzygania konkretnych spraw tylko wtedy, gdy nie zachodziła wlaściwość sądów niemieckich. W praktyce wyglądało to tak, że każda sprawa cywilna, w której stroną lub uczestnikiem postępowania byl podmiot niemiecki, podlegała sądownictwu niemieckiemu. Szczegółowe uregulowania dotyczące kwestii ustalenia właściwości sądów zostały znacznie rozbudowane. Sprawy toczące się już przed sądami polskimi przekazywano natychmiast niemieckim organom wymiaru sprawiedliwości, tworzonym na tzw. ziemiach wcielonych, jeśli według nowych przepisów organy te były whaściwe.

Sprawy karne badane były obowiązkowo przez niemiecką prokuraturę i ona decydowała, do jakiego pionu zostaną skierowane. Nawet sprawy rozpatrywane przez polskie organy już $w$ dniu wejścia $w$ życie powyższych przepisów, obojętne, w jakim stadium, miały być oddane władzom niemieckim. Orzeczenia już wydane miały stracić moc, jeśli postępowanie przejmowały sądy niemieckie. Co więcej, sprawy przekazane przez prokuraturę niemiecką sądom polskim mogły być powtórnie odebrane, aż do czasu uprawomocnienia się orzeczenia.

Podobne przepisy wprowadzono w zakresie spraw cywilnych. Sprawy zawisłe $w$ sądach polskich, a podlegające kompetencji sądów niemieckich, miały przechodzić obowiązkowo do rozpatrzenia przez te ostatnie. Jeśli toczyły się w pierwszej instancji, to przejmowal je sąd niemiecki, w innych przypadkach - wyższy sąd niemiecki. W razie istnienia jakiegokolwiek sporu o właściwość, sąd polski z urzędu lub na wniosek uczestnika postępowania przekazywał sprawę organom niemieckim. Kwestię rozstrzygały odpowiednio do stadium procesu: sąd niemiecki lub wyższy sąd niemiecki i było to rozstrzygnięcie wiążące ${ }^{55}$. Niska pozycja polskiego wymiaru sprawiedliwości wyrażała się także w tym, że ani polskie sądy, ani polska prokuratura nie mogły przesłuchiwać Niemców w charakterze świadków lub biegłych. Jeśli zachodzi taka konieczność, musiały zwrócić się do sądu niemieckiego, a ten przesłuchiwal biegłego lub świadka $w$ drodze pomocy prawnej, opierając się

${ }^{54}$ Prawo GG, A 120: Pierwsze rozporządzenie z 26 X 1939 r. o odbudowie administracji okupowanych polskich obszarów, \& 8; A. K la fk owski, Okupacja..., s. 59-60.

ss Prawo GG, C 148: Rozporządzenie z 19 II 1940 r. o przejściu spraw prawnych w sadownictwie niemieckim i polskim, $\S 1,2,3,5,6$. 
na przepisach procedury niemieckiej ${ }^{56}$. Wiadomo, że polskie sądy i prokuratura, mimo generalnego zakazu ingerowania w sprawy karne bez zgody władz niemieckich, musiały w pewnych przypadkach wszczynać niezbędne postępowanie. Otóż $w$ razie zwłoki grożącej niebezpieczeństwem organy te miały obowiązek podjąć wszelkie czynności, które służyć mogły wyjaśnieniu stanu rzeczy, zatrzymaniu obwinionego i zabezpieczeniu przedmiotów będących narzędziami przestępstwa. W budynku lub pomieszczeniu służącym celom zarządu niemieckiego sady polskie lub prokuratura mogły wykonywać czynności urzędowe tylko za uprzednią zgodą administracji niemieckiej, a o wszelkich nadzwyczajnych czynnościach musiały niezwłocznie informować prokuraturę niemiecką, która decydowała o dalszych losach sprawy ${ }^{57}$.

W celu kontrolowania prawomocnych orzeczeń sądów polskich wprowadzono instytucje zwaną prawem sprawdzenia. $Z$ wnioskiem o sprawdzenie wyroku występowal do wyższego sądu niemieckiego kierownik głównego wydziału sprawiedliwości w ciągu sześciu miesięcy od uprawomocnienia się. Przesłanką było naruszenie interesu publicznego. Wyższy sąd niemiecki mógł rozstrzygnięcie zatwierdzić lub je znieść; w tym drugim przypadku albo sam wyrokowal, albo przekazywal sprawę do sądownictwa niemieckiego. W sprawach cywilnych orzekal wówczas sąd niemiecki, a w sprawach karnych - sąd specjalny. Charakterystyczne jest, ze prawo sprawdzenia działało wstecz. Wszystkie wyroki sądów polskich, które uprawomocniły się po 31 sierpnia 1938 r., mogły zostać sprawdzone. Od tej i tak już bardzo niekorzystnej dla Polaków zasady uczyniono jeszcze dalej idący wyjątek, mianowicie: w szczególnie ważnych przypadkach, jeżeli rozstrzygnięcie naruszało interes narodu niemieckiego, orzeczenie mogło być sprawdzone bez względu na czas, jaki uplynął od momentu jego uprawomocnienia się ${ }^{58}$. Istniał jeszcze jeden sposób wzruszania prawomocnych wyroków sądów polskich. Jeśli obywatel Rzeszy lub osoba pochodzenia niemieckiego uważała, że nie dotyczące jej bezpośrednio orzeczenie narusza jednak jej interesy, mogła $w$ ciągu dwóch miesięcy zwrócić się ze skargą do wyższego sądu niemieckiego, który mial pełną swobodę decyzji co do dalszych losów sprawy ${ }^{59}$.

Obsadę sądów zmniejszono o okolo 50\%; w dniu 1 lipca $1940 \mathrm{r}$. zatrudniano 998 sędziów i prokuratorów, 2455 urzędników i 692 innych pracowników sądów i strażników więziennych ${ }^{60}$. W sądach przestały działać zgromadzenia ogólne sędziów i kolegia administracyjne, które przed wojną odgrywały istotną rolę $w$ rozstrzyganiu kwestii personalnych. Żydom unie-

s6 Prawo GG, C 151.

57 Prawo GG, C 120, \$ 17, 18, 19; C 150, \& 1, 2.

s8 A. W rzyszcz, $O$ organizacji okupacyjnego sqdownictwa polskiego $w$ Generalnym Gubernatorstwie w latach 1939-1945, „Zeszyty Majdanka” 1992, t. XIV, s. 116.

59 Prawo GG, C 120, §31, pkt 2.

$\infty$ BB, R 52 II, sygn. 247 , k. 54. 
możliwiono wykonywanie wszelkich zawodów prawniczych, a ich miejsce często zajmowali prawnicy wysiedleni z ziem wcielonych do Rzeszy.

Ogólnie postawa polskich sędziów i prokuratorów oceniana jest wysoko. Podjęli oni swoje obowiązki zawodowe, tak jak i inni pracownicy, na skutek nakazu administracyjnego wladz GG, ale starali się aktywnie kształtować warunki pracy. W Lublinie już 7 listopada 1939 r. odbyło się na przykład ogólne zebranie sędziów i prokuratorów, w celu omówienia sytuacji i ewentualnego kontynuowania pracy. W przyjętej wówczas rezolucji prawnicy ustalili kilka zasad niezbędnych dla funkcjonowania wymiaru sprawiedliwości w nowych, okupacyjnych warunkach. Postanowiono, że wszelka współpraca $\mathrm{z}$ okupantem jest wykluczona, jednakże konieczne jest zapewnienie opieki prawnej ludności polskiej, zabezpieczenie akt, dokumentów i ksiąg hipotecznych. Ustalono, że pracę będzie można kontynuować tylko wtedy, gdy sądom zostanie zapewniona niezależność w sądzeniu, język polski będzie językiem urzędowym i wyrokowanie będzie się odbywało pod neutralną formulą. Taka aktywna postawa niepokoiła Niemców, dlatego tak częste były aresztowania prawników (jako zakładników), bowiem wiedzieli o dużym ich wpływie na społeczeństwo. Postawę polskich prawników docenily władze polskie po II wojnie światowej, m. in. utrzymując w mocy wyroki polskich sądów z okresu okupacji ${ }^{61}$.

Zgodnie z obowiązującą w GG zasadą stosowania polskich przepisów, to o ile nie kolidowały wyraźnie $z$ niemieckimi, należy przyjać, że $w$ odniesieniu do palestry obowiązywało $w$ dalszym ciągu polskie przedwojenne prawo o ustroju adwokatury, które jednak Niemcy bardzo często naruszali. Jesienią 1939 r. polscy adwokaci reaktywowali swoje organizacje samorządowe. W Warszawie do 14 grudnia 1939 r. działala legalnie Naczelna Rada Adwokacka, jednak już na początku stycznia $1940 \mathrm{r}$. Niemcy rozwiązali warszawską Okręgową Radę Adwokacką. Analogicznie, tylko nieco wcześniej, bo w końcu 1939 r., postąpili z Okręgową Radą Adwokacką w Krakowie, natomiast w Lublinie zlikwidowano miejscową radę już 9 listopada 1939 r. Po tych represjach nadzór nad polską adwokaturą objęły wydziały sprawiedliwości funkcjonujące $w$ dystryktach. Powołały one komisaryczne władze adwokatury oraz utworzono tzw. Rady Przyboczne (,Beiraty”), które miały

${ }^{61}$ M. Sworzeń, Sqdownictwo..., s. 10-11; Z. Mańkowski, Między Wislq a Bugiem. Studium o polityce okupanta i postawach spoleczeństwa, Lublin 1982, s. 139-140; J. S z a r y cz, Sedziowie $i$ sqdy w Polsce $w$ latach 1918-1988, Warszawa 1988, s. 33-37; J. M a z u r k i e w i c z, L. Policha, Dzieje..., s. 45-46; A. Bień, Fragmenty wspomnień, „Więż” 1983, nr 11/12, s. 155; L. Chajn, Sqqdy a spoleczeństwo, „Demokratyczny Przegląd Prawniczy” 1945, nr 2, s. 9. Odmiennie na temat postawy polskich pracowników wymiaru sprawiedliwości wypowiada się G. Moritz. Podkreśla on klarowność przepisów regulujących rozdział sądownictwa polskiego od niemieckiego i lojalność polskich prawników wobec niemieckiej administracji; G. Moritz, Gerichtsbarkeit..., s. 73. 
charakter tylko doradczy. Drastycznym pogwałceniem prawa bylo skreślenie $\mathrm{z}$ list adwokackich wszystkich osób pochodzenia żydowskiego. $\mathrm{Za}$ bezprawie uznać należy także weryfikację przeprowadzoną przez wydzial sprawiedliwości dystryktu warszawskiego, która pozbawiła prawa wykonywania zawodu wielu adwokatów, z powodu ich działalności politycznej lub spolecznej $j^{62}$.

Polscy notariusze mogli wykonywać swój zawód $\mathrm{z}$ ograniczeniami wynikającymi $z$ prymatu prawa $\mathrm{i}$ sądownictwa niemieckiego (zob. wyżej), ale o wiele większa była ingerencja władz okupacyjnych $w$ funkcjonowanie samorządu notarialnego. Na początku 1940 r. obserwujemy prawie jednoczesną na całym okupowanym terenie akcje lokalnej administracji okupacyjnej zmierzającą do podporządkowania notariatu. Zmianie uległy obszary poszczególnych izb notarialnych: na terenie GG istniały cztery izby notarialne $\mathrm{z}$ siedzibami $\mathrm{w}$ Warszawie, Krakowie, Lublinie oraz $\mathrm{w}$ Radomiu, gdzie stworzono nową izbę notarialną $w$ związku $z$ ustanowieniem tam sądu apelacyjnego ${ }^{63}$. W Krakowie i Warszawie okupanci powołali komisarycznych zarządców izb notarialnych, którymi zostali dotychczasowi prezesi miejscowych rad notarialnych; podlegali oni nadzorowi wydziałów sprawiedliwości w poszczególnych dystryktach. Nieco inaczej sytuacja wyglądała w Lublinie. W polowie stycznia $1940 \mathrm{r}$. zwołano tam zebranie miejscowych notariuszy, na którym udzielone zostały zezwolenia na prowadzenie kancelarii. Nie otrzymal go dotychczasowy wiceprezes rady, a jego miejsce zająl asesor notarialny i dawny kierownik biura rady - Ukrainiec. W lutym $1940 \mathrm{r}$. w Lublinie wydział sprawiedliwości skonfiskował cały majątek rady, a na początku 1942 r. powolano komisarycznego kierownika. W Radomiu w czasie okupacji utworzono (nie istniejącą przed wojną) Izbę Notarialną. W ten sposób okupanci dokonali ujednolicenia terytorialnego podziału administracyjnego, z podziałem sądowym (powstał tu sąd apelacyjny); okręgi sądów apelacyjnych pokrywaly się z terytoriami dystryktów. Na początku $1942 \mathrm{r}$. przekazano z Lublina wszystkie akta osobowe notariuszy, zastępców notariuszy, asesorów notarialnych i aplikantów, którzy weszli w skład nowej Radomskiej Izby Notarialnej ${ }^{64}$.

${ }^{62}$ Kwestie organizacji i funkcjonowania adwokatury polskiej w czasie okupacji hitlerowskiej omawiane są $w$ wielu artykułach drukowanych w „Palestrze”. Wśród materiałów głównie wspomnieniowych, na czoło wysuwają się artykuły: W. Bayer, Konspiracyjna...; T. Z. K r zemiński, Adwokatura polska w okresie okupacji hitlerowskiej (1939-1945), "Palestra" 1976, nr 2; K. Ostrowski, Udzial adwokatów polskich w konspiracji wojskowej w okresie 1939-1945, „Palestra” 1983, nr 8, z których zaczerpnięto powyższe informacje.

${ }^{63}$ A. Wrzyszcz, Notariat..., s. 168.

of Izby notarialne w okresie wielkiej przerwy: 1939-1945, „Przegląd Notarialny” 1947, t. I, z. 2-3; Z. H ü bner, Izba Notarialna - Warszawa, s. 241-244; F. S zy ma n owicz, Izba Notarialna - Kraków, s. 247; J. B or k ow sk i, Izba Notarialna - Lublin, s. 532. Niestety nie odnalazłem bliższych informacji dotyczących funkcjonowania Izby Notarialnej w Radomiu. 
Ukształtowane w ciągu kilkunastu miesięcy roku 1939 i 1940 podstawy okupacyjnego systemu wymiaru sprawiedliwości w Generalnym Gubernatorstwie przetrwały w zasadzie do końca wojny. Można mówić tylko o pewnych modyfikacjach tej struktury po przyłączeniu do GG dystryktu Galicja. Uruchomiono tam sądownictwo niemieckie na takich samych zasadach, jak w pozostałych czterech dystryktach. Natomiast drugi pion nosil nazwę sądownictwa nieniemieckiego, które zorganizowano na wzór sądownictwa polskiego; Polacy w dystrykcie Galicja uzyskali identyczną pozycję jak Ukraińcy na pozostałym terytorium Generalnego Gubernatorstwa ${ }^{65}$. Poza tym $w$ trakcie okupacji wraz z pogarszającą się sytuacją wojenną III Rzeszy zwiększano sukcesywnie role sądownictwa doraźnego oraz policyjnych i wojskowych środków represji kosztem sądów powszechnych. Można także zaryzykować tezę, że wyraźnie zmniejszała się aktywność sądów pod koniec okupacji ${ }^{66}$. Kwestie te wymagają jednak dokładniejszego zbadania na podstawie zachowanych $\mathrm{w}$ archiwach polskich niemieckich i ukraińskich materiałów źródłowych.

${ }^{65}$ A. Wrzyszcz, Ustawodawstwo okupacyjne dla dystryktu Galicja 1941-1944, [w:] Studia $z$ historii państwa, prawa $i$ idei. Prace dedykowane Profesorowi Janowi Malarczykowi, red. A. Korobowicz, H. Olszewski, Lublin 1997, s. 493-494.

${ }^{66}$ J. Mazurkiewicz, Cz. Policha, Dzieje..., s. 37, 38, 47; J. Szarycz, Sedziowie..., s. 34-35; A. Wrzyszcz, $Z$ dzialalności..., s. 334. Podobne zjawisko zauważył i dokładnie przeanalizował A. Konieczny w orzecznictwie Sądu Specjalnego w Katowicach; A. K o n i e czny, Pod rzqdami..., s. 197-213. 